\title{
Epidemiology and antifungal susceptibility patterns of Candida species in tertiary hospitals: Update on regional trends
}

\author{
Epidemiologia e padrões de suscetibilidade antifúngica de espécies de Candida em hospitais \\ terciários: Atualização sobre tendências regionais \\ Epidemiología y patrones de susceptibilidad antifúngica de especies de Candida en hospitales \\ terciarios: Actualización sobre tendencias regionales
}

\begin{abstract}
Trends in epidemiology and antifungal susceptibility of Candida species in Brazil between 2019-2020 are reported. A total of 22 isolates diagnosed from candidemia episodes were analyzed. Candida species were identified by specie specific primer and/or sequencing of $28 \mathrm{~S}$ rDNA. Antifungal susceptibility was determined by CLSI method. . tropicalis accounted for $11(50 \%)$ cases followed by $C$. albicans $(\mathrm{n}=5,22.73 \%)$, C. parapsilosis $(\mathrm{n}=4$, $18.19 \%)$, Issatchenkia orientalis $(\mathrm{n}=1,4.54 \%)$, and Saccharomyces cerevisiae $(\mathrm{n}=1,4.54 \%)$. All Candida isolates were susceptible to amphotericin B and micafungin, and one was dose-dependent to anidulafungin. Eight of 20 Candida isolates were resistant to fluconazole and four sensitive doses dependent. Sixteen of 20 Candida isolates were resistant to voriconazole, and one resistant and one sensitive dose-dependent on caspofungin. Besides, the respective MIC50 and MIC90 values were calculated with fluconazole (MIC50 and MIC90 of 4 and $64 \mu \mathrm{g} / \mathrm{mL}$, respectively) and voriconazole (MIC50 and MIC90 of $16 \mu \mathrm{g} / \mathrm{mL}$ ) showing the lowest potencies. The spread of fluconazole-resistant in one of major concerns, especially to $C$. tropicalis. The high use of antifungal drug may be a possible cause related to this scenario.
\end{abstract}


Thus, the susceptibility profile test may be used to know the best way to introduce appropriateness empirical antibiotics therapy.

Keywords: Amphotericin B; Fluconazole; Yeasts; Diagnosis; Polymerase chain reaction.

\section{Resumo}

Tendências epidemiológicas e de susceptibilidade antifúngica de espécies de Candida no Brasil, entre 2019-2020, são relatadas. Um total de 22 isolados diagnosticados a partir de episódios de candidemia foram analisados. As espécies de Candida foram identificadas por meio de primer específico e/ou sequenciamento do domínio D1/D2, região 28S do rDNA. A susceptibilidade antifúngica foi determinada pelo método do CLSI. Candida tropicalis foi responsável por 11 $(50 \%)$ casos, seguido por C. albicans $(\mathrm{n}=5,22,73 \%)$, C. parapsilosis $(\mathrm{n}=4,18,19 \%)$, Issatchenkia orientalis $(\mathrm{n}=1$, $4,54 \%)$ e Saccharomyces cerevisiae $(\mathrm{n}=1,4,54 \%)$. Todos os isolados de Candida foram susceptíveis à anfotericina $\mathrm{B}$ e micafungina, e um foi dose-dependente à anidulafungina. Oito dos 20 isolados de Candida foram resistentes ao fluconazol e quatro susceptível dose dependente. Dezesseis dos 20 isolados de Candida foram resistentes ao voriconazol, um resistente e um susceptível dose-dependente a caspofungina. Além disso, os respectivos valores de MIC50 e MIC90 foram calculados com fluconazol (MIC50 e MIC90 de 4 e 64 $\mu \mathrm{g} / \mathrm{mL}$, respectivamente) e voriconazol (MIC50 e MIC90 de $16 \mu \mathrm{g} / \mathrm{mL}$ ) que apresentaram as potências mais baixas. A disseminação de espécies resistentes ao fluconazol é uma das principais preocupações, especialmente para C. tropicalis. O uso indiscriminado do antifúngico pode ser uma possível causa relacionada a esse cenário. Assim, a testagem do perfil de susceptibilidade pode ser usado para saber a melhor maneira de introduzir a terapia antibiótica empírica adequada.

Palavras-chave: Anfotericina B; Fluconazol; Levedura; Diagnostico; Reação em cadeia da polimerase.

\section{Resumen}

Se informan las tendencias epidemiológicas y de susceptibilidad antifúngica de especies de Candida en Brasil, entre 2019-2020. Se analizaron un total de 22 aislamientos diagnosticados de episodios de candidemia. Las especies de Candida se identificaron mediante cebador específico y/o secuenciación del dominio D1/D2, región 28S del rDNA. La susceptibilidad antifúngica se determinó mediante el método CLSI. Candida tropicalis fue responsable de 11 (50\%) casos, seguida de $C$. albicans $(\mathrm{n}=5,22,73 \%)$, . parapsilosis $(\mathrm{n}=4,18,19 \%)$, Issatchenkia orientalis $(\mathrm{n}=1,4,54 \%)$ y Saccharomyces cerevisiae $(\mathrm{n}=1,4,54 \%)$. Todos los aislados de Candida fueron sensibles a la anfotericina B y la micafungina, y uno fue sensible dosis dependiente a la anidulafungina. Ocho de los 20 aislados de Candida fueron resistentes al fluconazol y cuatro sensibles dosis dependiente. Dieciséis de los 20 aislados de Candida fueron resistentes al voriconazol, uno resistente y uno sensible dosis dependiente a la caspofungina. Además, se calcularon los valores respectivos de MIC50 y MIC90 con fluconazol (MIC50 y MIC90 de 4 y $64 \mu \mathrm{g} / \mathrm{mL}$, respectivamente) y voriconazol (MIC50 y MIC90 de $16 \mu \mathrm{g} / \mathrm{mL}$ ) que presentaron las potencias más bajas. La propagación de especies resistentes al fluconazol es una preocupación importante, especialmente para C. tropicalis. El uso indiscriminado de antifúngicos puede ser una posible causa relacionada con este escenario. Por lo tanto, la prueba del perfil de susceptibilidad se puede utilizar para encontrar la mejor manera de introducir una terapia antibiótica empírica adecuada.

Palabras clave: Anfotericina B; Fluconazol; Levadura; Diagnóstico; Reacción en cadena de la polimerasa.

\section{Introduction}

Invasive fungal infections comprise a group of disorders caused by Candida species. Invasive candidiasis may account for up to $80 \%$ of cases of invasive fungal infection, also resulting in an increased mortality rate (Yang et al., 2014). Besides, failures in diagnosis can result in delayed administration of antifungals, increased risk of death and costs involved in patient care (Bilir et al., 2015).

In now days, secondary fungal infections in ill patients may be inconspicuous and course to an aggressive infection and difficult to treat (Fan et al., 2020). Especially in aging people, episode of hyposalivation is common, and may be accompanied by the increased growth of Candida species in mucus tissue. In parallel, it is known that C. albicans interferes with E-cadherin resulting in epithelial invasion (Block, 2020).

Despite its great relevance, rapid and accurate diagnosis is still not a reality in public laboratories. In addition, the traditionally methods currently available are of little accuracy and low sensitivity (Van de Groep et al., 2018). Thus, the delay in diagnosis can result in a significant increase in the costs of treatment and hospital care for patients (Beyda et al., 2013; Zervou et al., 2017). Also, a current concern is the emergence of multidrug-resistant species and the epidemiological status of emerging yeasts. Thus, the prevalence of rare and uncommon species may be underestimated, with a very high attributable mortality rate (Kathuria et al., 2015; Kullberg, Arendrup, 2015). 
Although in recent decades, technological advances have been undeniable, largely due to the development of genomic and proteomic tools for the diagnosis of yeasts, their impact on health is still incipient, with rare and little use. The work developed in this field has been mainly focused on the field of bacteriology, immunology, and virology at the expense of fungi (Román et al., 2015; Day et al., 2018). Thus, the use of DNA as a diagnostic tool can be a valuable and superior approach to those obtained by conventional laboratory methods, represented by the microscopic examination and isolation of the etiological agent in culture. These characteristics end up conferring strong impacts on the therapeutic conduct and prognosis of invasive candidiasis.

\section{Methodology}

\section{Ethics aspects}

This is an experimental prospective study (Pereira et al., 2018), which included cases of mycosis in patients admitted to the Intensive Care Unit. The clinical samples were obtained from three tertiary hospitals from Recife, Brazil between July 2019 to March 2020. Ethics Committee board approved this research (CAEE number: 12993919.5.0000.5197) and the samples were obtained through a medical request. In addition, all material processing took place according to the Helsinki declaration.

\section{Mycological diagnosis}

The mycological diagnosis was made by preparing slides for direct microscopic examination and plating the sample on Sabouraud agar (DIFCO) containing 50mg/L of chloramphenicol and CHROMOAgar Candida. Soon after, the samples were kept at $30^{\circ} \mathrm{C}$ and $37^{\circ} \mathrm{C}$ for a period of up to 15 days. After obtaining the etiological agent, it was purified and identified through molecular taxonomy, when necessary.

\section{Species-specific diagnosis}

Our proposal consisted of using species-specific primers (Li et al., 2003; Asadzadeh et al., 2009) for diagnosis from the patient's biological sample. In this way, the samples used in the classical diagnosis were used in parallel for the molecular diagnosis. The test was validated using positive and negative predictive controls. Additionally, it was necessary to use other primers, such NL1-4 (Kurtzman; Robnett, 1997).

The DNA was extracted according to Inácio et al., (2016), where the biological samples were transferred to extraction tubes containing a glass bead matrix and $500 \mu \mathrm{L}$ of the extraction buffer (CTAB $2 \%, \mathrm{NaCl} 1.5 \mathrm{M}, 100 \mathrm{mM}$ Tris- $\mathrm{HCl}, 20 \mathrm{mM}$ EDTA, $1 \%$ polyvinylpyrrolidone) previously heated to $65^{\circ} \mathrm{C}$. After extraction, the DNA products were assembled in parafilm ( $5 \mu \mathrm{L}$ of the extraction product, $2 \mu \mathrm{L}$ GLB and $2 \mu \mathrm{L}$ GelRed), using the Lambda DNA marker as standard. The DNA was subjected to electrophoresis on $1.5 \%$ agarose gel containing the Tris-Acetate-EDTA (TAE) buffer, with a voltage of 100v for $20 \mathrm{~min}$. Subsequently, the DNA was analyzed for quality and quantity in a transilluminator. The genomic material was kept at $4{ }^{\circ} \mathrm{C}$ until the time of analysis.

For the in situ diagnosis of Candida infections, the methodology was adapted from Li et al. (2003) and Asadzadeh et al. (2009). Multiplex PCR reactions were performed in final volumes of $12.5 \mu \mathrm{L}$ containing $7.45 \mu \mathrm{L}$ of ddH2O, $1 \mu \mathrm{L}$ of each primer ( $5 \mathrm{pmol}), 1.25 \mu \mathrm{L}$ of the PCR buffer, $0.5 \mu \mathrm{L}$ of $\mathrm{MgCl} 2(50 \mathrm{mM}), 0.25 \mu \mathrm{L}$ of dNTP $(10 \mathrm{mM}), 0.05 \mu \mathrm{L}$ of $5 \mathrm{U}$ Taq DNA polymerase (Invitrogen, Brazil) and $1 \mu \mathrm{L}$ of DNA $(5 \mathrm{mM})$. PCR was performed in a thermocycler (Techne) according to the cycling parameters: initial denaturation at $95^{\circ} \mathrm{C}$ for $5 \mathrm{~min}$, performed in 30 cycles of $95^{\circ} \mathrm{C}$ for $30 \mathrm{~s}, 57^{\circ} \mathrm{C}$ for $30 \mathrm{~s}, 72^{\circ} \mathrm{C}$ for $30 \mathrm{~s}$ and a final extension at $72^{\circ} \mathrm{C}$ for $10 \mathrm{~min}$. The amplicons obtained were subjected to electrophoresis (100v for 20min) and photographed.

For species that are not identified at first, partial sequencing of the D1/D2 domain of the LSU (28S) region of the rDNA was performed using the NL1 and NL4 primers (Kurtzman; Robnett, 1997). The sequencing samples had the PCR products 
purified (GenJET PCR Purification - Fermentas, UK), and the sequencing was carried out on the Sequencing Platform-LABCEN / CCB (UFPE), according to internal protocols of the partner laboratory.

The consensus sequences were edited using the Sequencher 4.7 program and then submitted to the BLAST tool from GenBank (National Center of Biotechnology Information, http://www.ncbi.nlm.nih.gov) to search for similar sequences. The obtained sequences were aligned with confidence sequences deposited in the database and analyzed phylogenetically with the aid of the MEGA-x program.

\section{Determination of antifungal susceptibility profile}

The in vitro antifungal susceptibility test was performed according to the methods described in documents M27-A3 and M27-S4 of the Clinical and Laboratory Standards Institute (CLSI, 2008; CLSI, 2012). For the standardization of the experiment, the reference strain ATCC90028 (C. albicans) was used. For the test, the medium RPMI 1640 (Sigma-Aldrich, USA) buffered with morpholino propane sulfonic acid, pH 7.0 \pm 0.1 (MOPS; 0.165 mol.L-1; Sigma-Aldrich) was used. Yeasts were evaluated for their susceptibility profile to fluconazole, Amphotericin B, voriconazole, caspofungin, micafungin, and anidulafungin.

The yeasts were kept on Sabouraud Dextrose Agar (SDA) and incubated for 24 hours at $37^{\circ} \mathrm{C}$. Suspensions of the isolates were prepared in $0.85 \%$ saline, with the inoculum concentration adjusted by a spectrophotometer with a wavelength at $530 \mathrm{~nm}$, reflecting $90 \%$ of the transmittance. Then, the initial suspension was diluted to $2,5.10^{3}$ cells/mL in RPMI $1640.96-$ well flat-bottom micro-titration plates (TPP; Trasadingen, Switzerland) were used. The inoculum was added to the wells containing the drug solution to be tested, and the plates incubated at $37^{\circ} \mathrm{C}$ for $24-48 \mathrm{~h}$. The Minimum Inhibitory Concentrations (MICs) were determined with $100 \%$ inhibition for amphotericin B and $<50 \%$ concerning the control well for fluconazole and voriconazole.

The potency of the antifungals (MIC50 and MIC90) was determined by entering all the MIC values, for each isolate, in an Excel spreadsheet and ordering the data in ascending order. The MIC50 value was considered as the median MIC, while the MIC90 was the one that inhibited 90\% of the tested isolates (Drummond et al., 2003).

\section{Heatmap analysis}

A heatmaps generated for the MIC concentrations was evaluated using the R 3.6.2 program (R Core Team 2019). Euclidean distance was used to evaluate yeast clustering based on the Minimum Inhibitory Concentrations profile.

\section{Results and Discussion}

From July 2019 to March 2020, 202 patients from the Hospital das Clínicas-UFPE (n = 178/200, 89\%), Hospital Agamenon Magalhães (17/200, 8.5\%) and Hospital de Cancer de Pernambuco ( $\mathrm{n}=5 / 200$ patients, $2.5 \%)$. 22 (11\%) patients were eligible for the study because they had a compatible and proven picture of systemic/deep fungal infection.

During the period, a higher incidence was observed for Candida non-Candida albicans species, being recovered and/or detected, from blood samples, 10 (39.13\%) isolated from C. tropicalis accounted for 11 (50\%) cases followed by C. albicans $(\mathrm{n}=5,22.73 \%)$, C. parapsilosis $(\mathrm{n}=4,18.19 \%)$, Issatchenkia orientalis $(\mathrm{n}=1,4.54 \%)$, and Saccharomyces cerevisiae $(\mathrm{n}=1$, $4.54 \%)$.

An elevated incidence was observed in male patients $(n=13 / 24,54.2 \%)$, while in women it was slightly lower $(n=$ $11 / 24,45.8 \%$ ). Regarding the average age of the affected patients, there was a considerable variation, with a greater incidence being noted in individuals of advanced age, especially in the age group of 60 years or more (32\%). The average age of men was 42.93 years ( 0 to 93 years), while for women this value was 40.87 years (0 to 77 years).

Concerning the diagnostic proposal developed in this research, the diagnosis made from the biological sample represented a significant gain in the microbiological diagnosis, especially for cases of candidemia in which it was not possible 
to observe fungal structures in parasitism and/or isolate the etiological agent. Still, no interference was found during the performance of the PCR. This was initially a barrier to be overcome, given the possibility of DNA polymerase inhibitors obtained during the process of collection and/or extraction of biological material, such as heme hemoglobin groups (Sambrook et al., 1989). Also, $\mathrm{Fe}^{2+}$ ions can actively compete with $\mathrm{Mg}^{2+}$ ions, the latter being indispensable for the activation of DNA polymerase. It is possible that this inhibitor is not inhibited by the action of proteinases and organic solvents (An; Fleming, 1991). However, we found that the protocol used yielded an adequate genetic material, at a low cost, for diagnosis and molecular identification.

Microscopic examination showed yeast cells, yeast and septate hyaline mycelial filaments. Nineteen patients presented candidemia proven by the traditional approach $(19 / 23,82.6 \%)$ and 22 by the PCR technique $4(23 / 23,100 \%)$. In three patients, it was not possible to obtain the etiological agent in culture. However, the molecular approach, based on the use of primers, was more sensitive, specific and quicker than the traditional method of microbiological diagnosis. Thus, in two cases it was possible to establish the diagnosis and the identity of the etiologic agent using the specific species primers, one by $C$. tropicalis and the other by $C$. parapsilosis. In one case, the diagnosis was only possible after partial sequencing of the D1/D2 region of the $28 \mathrm{~S}$ subunit of rDNA such as $S$. cerevisiae.

The chromogenic CHROMOAgar Candida medium was used to differentiate between the different strains of the study. It was observed that this medium presented a sensitivity of $86.67 \%$ in the interspecific differentiation of species. However, 2 isolates of $C$. albicans showed a bluish color, differing from what is typical for the species. In the case of the species of $C$. parapsilosis (5) and Issatchenkia orientalis (1), these exhibited beige and purple tones, respectively. Although not a definitive aspect, these characteristics can serve as a basis for choosing a more accurate identification method. In the case of diagnosis, it was observed that after plating the biological sample directly into the CHROMOAgar Candida medium, the isolates exhibited the same profile as the isolated and purified strain (Table 1).

Table 1. Agreement profile between the taxonomic confirmation of the isolates and the CHROMOAgar Candida chromogenic medium.

\begin{tabular}{llll}
\hline $\begin{array}{l}\mathrm{N}^{\circ} \text { of } \\
\text { yeasts }\end{array}$ & \multicolumn{1}{c}{$\begin{array}{c}\text { Genomic } \\
\text { confirmation }\end{array}$} & $\begin{array}{l}\text { Agreement between } \\
\text { CHROMOAgar Candida and } \\
\text { identification }\end{array}$ & $\begin{array}{l}\text { Coloring displayed in the } \\
\text { CHROMOAgar Candida medium }\end{array}$ \\
\hline 9 & Candida tropicalis & $100 \%(9 / 9)$ & Blue \\
5 & C. albicans & $60 \%(3 / 5)$ & Green and/or blue \\
5 & $\begin{array}{l}\text { C. parapsilosis } \\
\text { Issatchenkia }\end{array}$ & $-100 \%(1)$ & Beige and/or White \\
1 & orientalis & & Pink \\
\hline
\end{tabular}

Source: Authors.

Similar to the data presented here, Li et al. (2003) also reported the usefulness of the chromogenic medium in the early detection of clinical Candida isolates from the biological sample. The CHROMagar Candida medium is a selective and differential culture medium in the identification of C. albicans, C. tropicalis and Issatchenkia orientalis species (Becton Dickinson GmbH, 2014). Thus, this culture medium can also be used in the isolation and early identification of Candida species from the biological sample (Silva et al., 2018). Sadrossadati et al. (2018), reported a significant agreement in the identification of clinical isolates of $C$. albicans $(n=128 / 129,99.2 \%)$, C. tropicalis $(n=13 / 14,92.86 \%)$ and . grabrata $(n=18 / 22,81.81 \%)$.

Regarding the molecular approach, this method allowed to obtain more solid results. The samples that reacted to the specific species primers $(n=17 / 20,85 \%)$ were, simultaneously, positive for the molecular diagnosis and confirmatory for the species in question. Except for three isolates (16049, 15739 and 1003), the species-specific primers ( $\mathrm{n}=17 / 20,85 \%)$ were able to discriminate the isolates of the species obtained by comparing the size of the fragment generated with the pattern of each 
species (C. albicans-402pb, C. tropicalis-149pb, C. parapsilosis (379pb) and, Issatchenkia orientalis-475pb) (Li et al., 2003; Asadzadeh et al., 2009).

Initially, non-reactive samples were only positive after using primers NL1 and NL4. Thus, possible candidemia by $S$. cerevisiae and/or a sub-species of $C$. albicans was found. This fact is under investigation, and one reason for the nonamplification of the DNA of isolates 16049 and 15739 by the specific primers is the possibility that these strains are a subspecies of Candida albicans. This fact can be seen in phylogenetic analyzes, with a great similarity between the DNA of yeast isolates (Alonso-Vargas et al., 2008).

\section{Susceptibility profile of clinical isolates}

In this work, all Candida isolates were susceptible to amphotericin B and micafungin. Regarding anidulafungin, eighteen isolates were sensitive and one strain was dose-dependent. However, this scenario was different and worrying compared to fluconazole, voriconazole, and caspofungin. Thus, 8 resistant strains and 4 sensitive doses dependent on fluconazole, 16 resistant strains and 2 sensitive doses dependent on voriconazole and 1 resistant strain and 1 sensitive dose-dependent on caspofungin were observed (Table 2). 
Table 2. Determination of the Minimum Inhibitory Concentration (MIC) of the antifungals amphotericin B (Anf), fluconazole (Flu), voriconazole (Vor), caspofungin (Cas), micafungin (Mic) and anidulafungin (Ani) against the clinical isolates of Candida sp. A color map was used to represent the susceptibility profile of the isolates, using the colors green (susceptible), yellow (susceptible dose dependent) and red (Orange).

\begin{tabular}{lllcccccc}
\hline Strain & GenBank access & Yeast isolate & \multicolumn{3}{c}{ Minimum Inhibitory Concentration $(\mu \mathrm{g} / \mathrm{mL})$} \\
& code & & & & & & & \\
\hline \multirow{2}{*}{$6 \mathrm{~K}$} & & & Anf & Flu & Vor & Cas & Mic & Ani \\
\cline { 4 - 9 } 1173 & MW829750 & Issatchenkia orientalis & 0,25 & 64 & 16 & 0,25 & 0,03 & 0,06 \\
1697 & MW829734 & C. albicans & 0,125 & 8 & 16 & 0,125 & 0,03 & 0,03 \\
15739 & MW861537 & C. albicans & 0,25 & 0,5 & 8 & 0,06 & 0,03 & 0,03 \\
17107 & MW829732 & C. albicans & 0,25 & 4 & 16 & 0,125 & 0,03 & 0,03 \\
316049 & MW861538 & C. albicans & 0,25 & 0,25 & 16 & 0,125 & 0,03 & 0,03 \\
$6 \mathrm{~T}$ & MW829740 & C. tropicalis & 0,25 & 4 & 16 & 0,125 & 0,03 & 0,03 \\
50 & MW829742 & C. tropicalis & 0,5 & 32 & 4 & 1 & 0,06 & 0,125 \\
416 & MW829743 & C. tropicalis & 0,5 & 0,5 & 16 & 0,06 & 0,06 & 0,06 \\
1047 & MW829744 & C. tropicalis & 0,25 & 64 & 16 & 0,03 & 0,06 & 0,03 \\
1175 & MW829745 & C. tropicalis & 0,03 & 32 & 16 & 0,06 & 0,03 & 0,03 \\
1345 & MW829746 & C. tropicalis & 0,125 & 64 & 16 & 0,25 & 0,03 & 0,06 \\
3160 & ------------ & C. tropicalis & 1 & 32 & 16 & 0,5 & 0,03 & 0,125 \\
15745 & MW829738 & C. tropicalis & 0,125 & 0,5 & 16 & 0,06 & 0,06 & 0,03 \\
17751 & MW829741 & C. tropicalis & 0,25 & 4 & 16 & 0,06 & 0,03 & 0,03 \\
516197 & MW829739 & C. tropicalis & 0,25 & 32 & 16 & 0,25 & 0,03 & 0,125 \\
109 & ------------ & C. parapsilosis & 0,25 & 0,5 & 16 & 0,125 & 0,03 & 0,03 \\
3453 & ------------ & C. parapsilosis & 0,25 & 0,5 & 0,5 & 0,125 & 0,06 & 0,03 \\
415813 & MW829749 & C. parapsilosis & 0,25 & 0,5 & 0,125 & 0,125 & 0,03 & 0,06 \\
MIC50 & & & 0,25 & 0,5 & 0,25 & 1 & 2 & 4 \\
MIC90 & & & 0,25 & 4 & 16 & 0,125 & 0,03 & 0,03 \\
\hline & & & 0,5 & 64 & 16 & 1 & 0,06 & 0,125 \\
\hline
\end{tabular}

Source: Authors.

Besides, the respective MIC50 and MIC90 values were calculated to know the intrinsic susceptibility profile of each drug evaluated against the main yeast agents. It was noted that, among the antifungals used, fluconazole (MIC50 and MIC90 of 4 and $64 \mu \mathrm{g} / \mathrm{mL}$, respectively) and voriconazole (MIC50 and MIC90 of $16 \mu \mathrm{g} / \mathrm{mL}$ ) showed the lowest potencies, signaling a possible ineffectiveness of drugs in the yeast treatment. These values represent MIC are geometric means that represent, respectively, the concentrations necessary to inhibit $50 \%$ and $90 \%$ of the number of isolates. Thus, the knowledge of these values consists of very relevant information from a clinical and epidemiological point of view, since they make it possible to know the potency of antifungals to the etiological agents involved in cases of serious infections in a given period (Table 2). 
Figure 1. Heatmap analisys of the in vitro antifungal susceptibility test of the drugs amphotericin B (Anf), fluconazole (Flu), voriconazole (Vor), caspofungin (Cas), micafungin (Mic) and anidulafungin (Ani) against the clinical isolates of Candida sp.

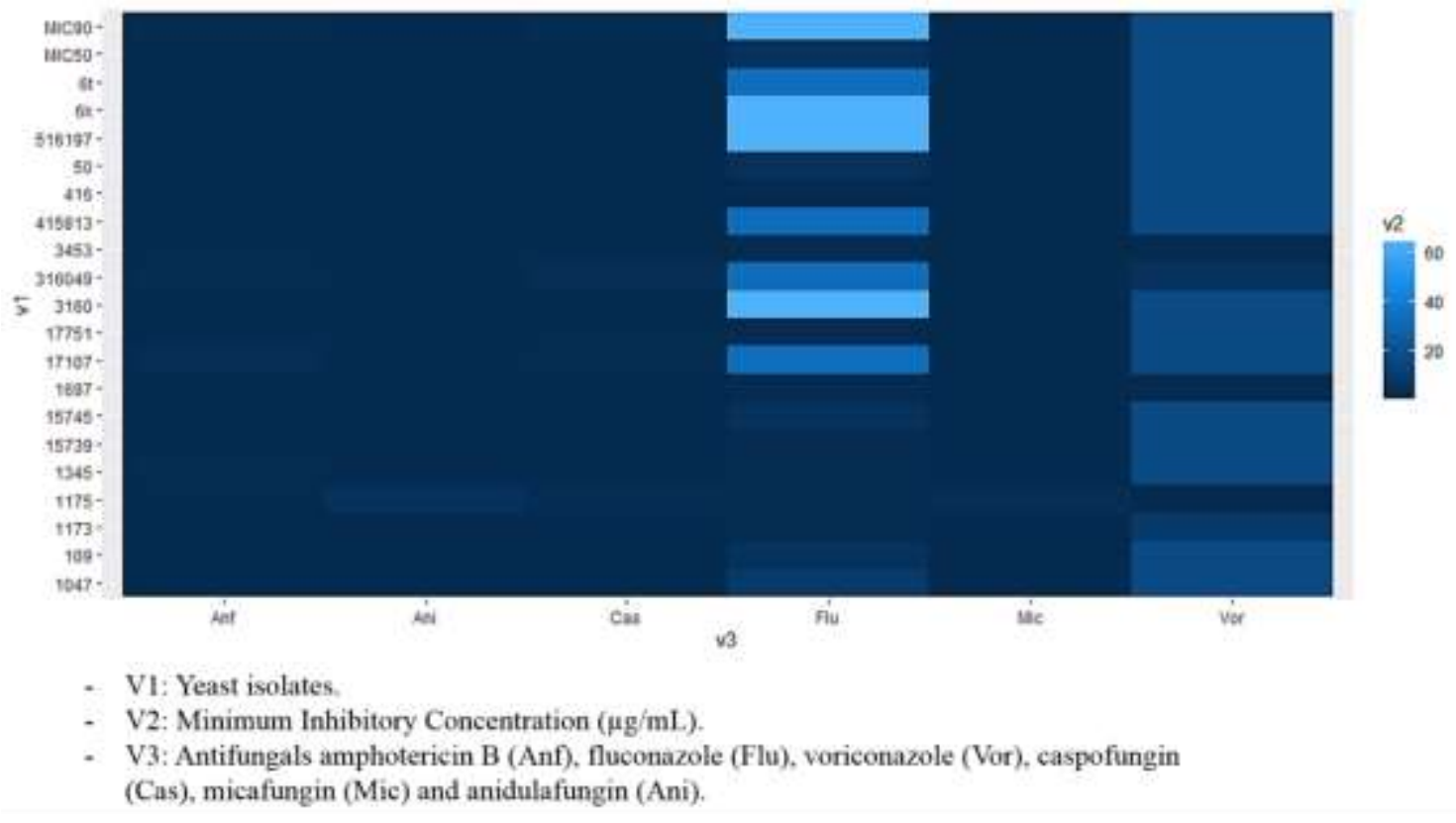

Source: Authors.

A heatmap analysis based on the antifungal susceptibility results of the 19 clinical yeast isolates against amphotericin $\mathrm{B}$, fluconazole, voriconazole, caspofungin, micafungin and anidulafungin allowed the separation this antifungal agents in three groups. The yeast isolates were more inhibited by amphotericin B, caspofungin, micafungin and anidulafungin. However, fluconazole and voriconazole were more ineffective against of the pathogens (Fig. 1), confirming the effect of the resistance phenomenon among these species of Candida.

A relevant data observed was the higher incidence of Candida non-Candida albicans species. The data obtained here are similar to other studies that point to a variation in the prevalence of Candida, with C. tropicalis occupying a prominent position (Fagan et al., 2013; Da Costa et al., 2014). In a scenario of lack of comprehensive epidemiological data on fungal infections, it may represent a limiting factor in the knowledge about this problem. Studies have been developed to try to respond to this change in the pattern of species distribution. In this sense, Lortholary et al. (2011) developed a possible explanation for the establishment of this new paradigm centered on empirical treatment. The authors report that a recent exposure of Candida isolates to fluconazole may result in a lower incidence of $C$. albicans. The authors also noted that the risk of infection can increase by 4.75 times (Odds ratio) in patients over 15 years of age.

An increased frequency was observed for species resistant to fluconazole and voriconazole. Recent work has reported similar patterns related to increased resistance to these antifungals. The spread across the globe of resistant isolates and the few therapeutic options available has negatively influenced the treatment and prognosis of patients (Sharafutdinov, et al., 2020). Candida albicans species, especially the emerging ones, have significantly influenced the clinical course of patients around the world. Currently, the most recent guidelines for the treatment of fungal infections have recommended fluconazole as a primary therapeutic option to combat these infections. However, there have been increasing reports of increased resistance inherent to this drug. Another worrying factor concerns the great variability of inter- and intra-species resistance, as well as the emergence of unknown mechanisms of resistance to fluconazole that can represent a global health threat (Berkow, Lockhart, 2017). 
Another aggravating factor is the fact that in underdeveloped countries, such as Brazil, there is a limitation of financial resources that can cover the entire system's demand (Stewart; Wild, 2014). Thus, knowledge about how Candida species show resistance to fluconazole is extremely important, since it is one of the most essential drugs available today.

The future outlook for invasive fungal infections is uncertain. In the last decade, yeast infections were the fourth leading cause of nosocomial infection (Rangel-Frausto et al., 1999; Wisplinghoff et al., 2004). However, studies have pointed to a change in direction in the positioning of the etiological agents. In this sense, according to Wisplinghoff et al. (2004) and Fagan et al. (2013), these agents can occupy the third position, behind only infections caused by Staphylococcus aureus and S. epidermidis, with a high incidence rate ( 0.25 per 1,000 inhabitants). Thus, the use of refined tools for the correct identification of the etiological agents and the determination of the susceptibility pattern of the isolates to antifungals are vital, given that they enable the knowledge of the epidemiological pattern and the direction of the therapeutic conduct.

\section{Final Considerations}

The use of molecular tools is crucial to obtain an accurate and precise laboratory diagnosis. In addition to this, knowledge of the antifungal susceptibility profile can assist in directing the most effective treatment of the infection. Still, the emergence of species resistant to fluconazole is a scenario that deserves attention, especially in the species of Candida nonCandida albicans. Today, the spread of fluconazole-resistant is one of major concerns, especially to C. tropicalis. The high use of antifungal drug may be a possible cause related to this scenario. Thus, the susceptibility profile test may be used to know the best way to introduce appropriate empirical antibiotics therapy.

\section{Funding}

This work was supported by the Fundação de Apoio a Ciência e Tecnologia do Estado de Pernambuco (FACEPE) for granting of scholarships to C.P.I. (BFP-0094-2.12/20) and the Coordenação de Aperfeiçoamento de Pessoal de Nível Superior (CAPES) (grant number 88887.312033/2018-00).

\section{References}

Asadzadeh, M. et al. (2009). Rapid molecular differentiation and genotypic heterogeneity among Candida parapsilosis and Candida orthopsilosis strains isolated from clinical specimens in Kuwait. Journal of Medical Microbiol. 58(1), 745-52.

An, S. F., \& Fleming, K. A. (1991). Removal of inhibitors of the polymerase chain reaction from formalin fixed, paraffin-wax embedded tissues. Journal of Clinical Pathology, 44(11), 924-927.

Berkow, E. L., \& Lockhart, S. R. (2017). Fluconazole resistance in Candida species: A current perspective. Infection and Drug Resistance, $10,237-245$.

Becton Dickinson GmbH. (2014). Instruções de utilização - meios em placas prontos a usar: BD $^{\mathrm{TM}}$ CHROMagar $^{\mathrm{TM}}$ Candida Medium.

Beyda, N. D., et al. (2013). Comparison of the T2Dx instrument with T2Candida assay and automated blood culture in the detection of Candida species, Diagnostic Microbiology and Infectious Disease, 77(4), 324-6.

Bilir, S. P., Ferrufino, C. P., Pfaller, M. A., \& Munakata, J. (2015). The economic impact of rapid Candida species identification by T2Candida among highrisk patients. Future Microbiology, 10(7), 1133-44.

Clinical and Laboratory Standards Institute (CLSI) (2008). Reference method for broth dilution antifungal susceptibility testing of yeasts; approved standard, 3rd ed. CLSI document M27-A3. CLSI, Wayne, PA.

Clinical and Laboratory Standards Institute (CLSI) (2012). Reference method for broth dilution antifungal susceptibility testing of yeasts; CLSI document M27S4. CLSI, Wayne, PA.

Da Costa, V. G. et al. (2014). Nosocomial bloodstream Candida infections in a tertiary-care hospital in South Brazil: A 4-year survey. Mycopathologia, 178, $243-250$.

Day, A. M., McNiff, M. M., da Silva, D. A., Gow, N. A.R., \& Quinn, J. (2018). Hog1 Regulates Stress Tolerance and Virulence in the Emerging Fungal Pathogen Candida auris. MSphere, 24, 3-5. 
Drummond, L. J. et al. (2003). Changes in sensitivity patterns to selected antibiotics in Clostridium difficile in geriatric in-patients over an 18-month period. Journal of Medical Microbiology, 52, 259-263.

Fagan, R. P. et al. (2013). Incidence trends in pathogen-specific central line-associated bloodstream infections in US intensive care units, 1990-2010. Infection Control \& Hospital Epidemiology, 34(9), 893-9.

Van De Groep, K. et al. (2018). Development and first evaluation of a novel multiplex real-time PCR on whole blood samples for rapid pathogen identification in critically ill patients with sepsis. European Journal of Clinical Microbiology \& Infectious Diseases, 37(7), $1333-1344$.

Inácio, C. P. et al. (2016). Experimental white piedra: a robust approach to ultrastructural analysis, scanning electron microscopy and etiological discoveries. Experimental Dermatology, 25(1), 79-81.

Kathuria, S., et al. (2015). Multidrug-Resistant Candida auris Misidentified as Candida haemulonii: Characterization by Matrix-Assisted Laser Desorption Ionization-Time of Flight Mass Spectrometry and DNA Sequencing and Its Antifungal Susceptibility Profile Variability by Vitek 2, CLSI Broth Microdilution, and Etest Method. Journal of Clinical Microbiology, 53(6), 1823-30.

Kullberg, B. J., \& Arendrup, M. C. (2015). Invasive Candidiasis. New England Journal of Medicine, 373(15), 1445-56.

Kurtzman, C. P., \& Robnett C. J. (1997). Identification of clinically important ascomycetous yeasts based on nucleotide divergence in the 5'end of the largesubunit (26S) ribosomal DNA gene. Journal of Clinical Microbiology, 35, 1216-1223.

Li, Y. L., Leaw, S. N., Chen, J. H. et al. (2003). European Journal of Clinical Microbiology \& Infectious Diseases, $22,693$.

Lortholary, O. et al. (2011). Recent exposure to caspofungin or fluconazole influences the epidemiology of candidemia: a prospective multicenter study involving 2,441 patients. Antimicrobial Agents and Chemotherapy, 55(2), 532-8.

Pereira, A. S. et al. (2018). Metodologia da pesquisa cientifica. UFSM.

Rangel-Frausto, M. S. et al. (1999). National Epidemiology of Mycoses Survey (NEMIS): Variations in Rates of Bloodstream Infections Due to Candida Species in Seven Surgical Intensive Care Units and Six Neonatal Intensive Care Units. Clinical Infectious Diseases, 29(2), $253-258$.

Román, E., Alonso-Monge, R., Miranda, A., \& Pla, J. (2015). The Mkk2 MAPKK Regulates Cell Wall Biogenesis in Cooperation with the Cek1-Pathway in Candida albicans. PLoS One, 21, 1-7.

Sambrook, J., Fritch, E. F., \& Maniatis, T. (1989). Molecular cloning: A Laboratory Manual. (2a ed.), Cold Spring Harbor Laboratory Press.

Sharafutdinov, I. S. et al. (2020). Increasing Susceptibility of Drug-Resistant Candida albicans to Fluconazole and Terbinafine by $2(5 H)$-Furanone Derivative. Molecules, 25(3), 642.

Sadrossadati, S. Z. et al. (2018). Phenotypic and genotypic characterization of Candida species isolated from candideamia in Iran. Current Medical Mycology, 4(2), 14-20.

Silva, J. J. D. et al. (2018). Candida species biotypes in the oral cavity of infants and children with orofacial clefts under surgical rehabilitation. Microbial Pathogenesis, 124, 203-215.

Stewart, B. W., \& Wild, C. P. (editors) (2014). World cancer report 2014. International Agency for Research on Cancer - IARC.

Yang, H. P., Tsang, P. C., \& Tsang, P. W. (2014). Melatonin inhibits biofilm formation in Candida parapsilosis. Journal De Mycologie Medicale, 24(4), 3601.

Wisplinghoff, H. et al. (2004). Nosocomial Bloodstream Infections in US Hospitals: Analysis of 24,179 Cases from a Prospective Nationwide Surveillance Study. Clinical Infectious Diseases, 39(3), 309-317.

Zervou, F. N., Zacharioudakis, I. M., Kurpewski, J., \& Mylonakis, E. (2017). T2 Magnetic Resonance for Fungal Diagnosis. Methods in molecular biology, 1508, 305-319. 